\title{
Comparing risk in conventional and organic dairy farming in the Netherlands: An empirical analysis
}

\author{
P. B. M. Berentsen, ${ }^{1}$ K. Kovacs,, and M. A. P. M. van Asseldonkł \\ *Business Economics Group, Wageningen University, PO Box 8130, 6700 EW Wageningen, the Netherlands \\ †Department of Agribusiness Management, Faculty of Applied Economics and Rural Development, University of Debrecen, Böszörményi str. 138, \\ 4032 Debrecen, Hungary \\ $\ddagger$ Agricultural Economics Research Institute, Wageningen University and Research Centre, PO Box 8130, 6700 EW Wageningen, the Netherlands
}

\begin{abstract}
This study was undertaken to contribute to the understanding of why most dairy farmers do not convert to organic farming. Therefore, the objective of this research was to assess and compare risks for conventional and organic farming in the Netherlands with respect to gross margin and the underlying price and production variables. To investigate the risk factors a farm accountancy database was used containing panel data from both conventional and organic representative Dutch dairy farms (2001-2007). Variables with regard to price and production risk were identified using a gross margin analysis scheme. Price risk variables were milk price and concentrate price. The main production risk variables were milk yield per cow, roughage yield per hectare, and veterinary costs per cow. To assess risk, an error component implicit detrending method was applied and the resulting detrended standard deviations were compared between conventional and organic farms. Results indicate that the risk included in the gross margin per cow is significantly higher in organic farming. This is caused by both higher price and production risks. Price risks are significantly higher in organic farming for both milk price and concentrate price. With regard to production risk, only milk yield per cow poses a significantly higher risk in organic farming.
\end{abstract}

Key words: dairy farming, organic farming, risk assessment, error component implicit detrending method

\section{INTRODUCTION}

The adverse environmental impact of many intensive production systems has increased the demand for more sustainable agricultural production systems. Organic farming is recognized as a possible way forward to im-

Received November 28, 2011.

Accepted February 25, 2012.

${ }^{1}$ Corresponding author: Paul.Berentsen@wur.nl prove sustainability in agriculture (Rigby and Cáceres, 2001; Padel et al., 2002). The main aim of organic farming is to create a sustainable agricultural production system including economic, environmental, and social sustainability (Padel, 2001). Organic farming claims to have the potential to provide benefits in terms of environmental protection, conservation of nonrenewable resources, improved food quality, reduction in output of surplus products, and the reorientation of agriculture toward areas of market demand (Lampkin, 1994).

In the countries belonging to the European Union (EU), legislation regarding organic farming is based on EU Council Regulation (EC) No. 2092/1991 (European Council, 1991) and on EU Council Regulation (EC) No. 1804/1999 (European Council, 1999). In the Netherlands, implementation and control of the legislation on organic farming is taken care by the organization Stichting Skal (Zwolle, the Netherlands). Organic farming is, thus, defined and distinguished from conventional farming by a set of injunctions. For organic dairy farming, these injunctions deal with grass and roughage production (ban on the use of artificial fertilizers), grassland management (during the growing season, grazing of all animals is prescribed), feeding (on a DM basis, concentrate use may never be more than $40 \%$ of the daily ration; concentrates and purchased roughage have to be organically produced), and animal health care (e.g., ban on preventive use of antibiotics and other regular medicine; a maximum of 3 curative treatments with antibiotics and other regular medicine per animal per year; Stichting Skal, 2012).

Recognizing the potential benefits of organic farming, governments encourage farmers to adopt organic farming practices, either directly through financial incentives or indirectly through support of research, extension, and marketing initiatives (Acs et al., 2007). Regarding economic results of organic farming, both empirical studies (Stonehouse et al., 2001; Butler, 2002) and normative studies (Acs et al., 2007; Rotz et al., 2007) show better economic results for organic farming. A common aspect in all of these studies explaining the 
enhanced economic results of organic farming is higher farm gate prices of organic products.

In spite of these enhanced economic results, and governmental support for organic farming the vast majority of farms in the Netherlands (98\% of the dairy farms and $96 \%$ of the arable farms in 2011) are still farming conventionally (LEI, 2012). A reason for farmers not to convert to organic farming might be a potentially higher risk exposure in organic farming. Production risks might be increased because farmers need to learn new ways of working in which they can rely less on external inputs (fertilizers, pesticides, and feedstuffs) to manage the production process. Price risk might be higher because organic products are often sold at small niche markets where prices can be quite volatile, whereas, especially in the EU, price protection for several conventionally produced agricultural commodities (e.g., milk) is high, leading to stable prices. However, the situation may turn around in the future when EU price protection will be gradually decreased and world market prices will be the reference for conventionally produced agricultural commodities.

Farmers need to apply risk management strategies to balance their profits and risks. Therefore, risk analysis and risk modeling are important to support farm-level decision making.

Risk analysis focuses on the changes of occurrence of a risk and assesses the consequences, given current risk management practice (Hardaker et al., 2004). Comparison of risk between conventional and organic farming in arable farming (Acs et al., 2009) showed that risks in organic farming were considerably higher. For dairy farming, studies comparing risk of diseases, influencing production for conventional and organic farms, have been undertaken (Hardeng and Edge, 2001; Roesch et al., 2005; Ray et al., 2006). These studies show that the health status of cows on organic farms is generally better, so disease risk is lower on organic than on conventional farms.

Risk models have been applied to rationalize the choice of converting from conventional to organic farming (Flaten and Lien, 2007). These models generally include judgments about the level of the risk and the preference of the decision maker (Ogurtsov et al., 2008).

Modeling subjective judgments requires capturing the degree of belief of a decision maker (i.e., risk perception). Risk perception is more like the mental interpretation of risk, broken down into the chance of being exposed to the content and the magnitude of the risk. Dutch farmers perceive production and price risk as most important to them (Huirne et al., 2007), whereas Ogurtsov et al. (2009) show that risk perception affects the decision of Dutch dairy farmers.
Similar to risk perception, risk attitude plays an important role in understanding and modeling the decision maker's behavior. Risk attitude is the extent to which a decision maker seeks to avoid risk (i.e., risk aversion) or prefers to face risk (i.e., risk preference). Most farmers are commonly assumed to be risk averse (Hardaker et al., 2004), and this also holds for Dutch dairy farmers (Ogurtsov et al., 2009). Gardebroek (2006) found that, on average, organic farmers have significantly lower coefficients of risk aversion than nonorganic farms, supporting the hypothesis that organic farmers tend to be less risk averse than their nonorganic colleagues.

At farm level, an overall empirical risk assessment for conventional and organic dairy farming is still lacking. The objective of this research was to assess and compare risk for conventional and organic farming in the Netherlands, both regarding income and underlying price and production aspects.

\section{MATERIALS AND METHODS}

This section starts with a description of the database, followed by the selection of the variables and a description of necessary additional calculation of the risk variables. Next, the method of analyzing the data to determine differences in risk between conventional and organic farms is described.

\section{Description of the Data}

The analysis was based on Dutch dairy farm data for the years 2001 to 2007, recorded via the Farm Accountancy Data Network (FADN) of the Agricultural Economics Research Institute (Wageningen, the Netherlands). The FADN consists of an annual survey carried out by the member states of the European Union. To ensure representative data, in each member state, a random sample is constructed, including approximately $2 \%$ of the farms, and based on 3 criteria: region, economic size, and type of farming. Type of farming indicates the most important agricultural activity or set of activities on a farm (for example, arable farming, dairy farming, or mixed farming). For arable and dairy farming, the type of farming includes the conventional and the organic variant. The survey is a rotating survey, meaning that the number of years farms are in the survey can differ among farms. The advantage of FADN is that it is a harmonized data source with similar bookkeeping principles in all member states. A further advantage, which is explicitly used in this research, is the microeconomic nature of the data source. Detailed information is available on individual holdings, which provides the opportunity to conduct analysis on 
a holding level and gives insight in the distribution and differences in incomes between holdings. Furthermore, it makes it possible to follow the performance of a farm during consecutive years (Court of Auditors, 2004).

The total number of specialized dairy farms in the database available for this analysis was 386 . Because of the interest in within-farm standard deviations, farms that were only in the database for $1 \mathrm{yr}$ were excluded from the analysis. Of the remaining farms (348), the majority were conventional farms (302), whereas 46 were organic. The farms in the database were either conventional or organic for the whole analysis period, so transition between conventional and organic was not observed. The average number of years farms were in the in the database was $5.5 \mathrm{yr}$ for conventional and 4.4 yr for organic farms.

The database contains both technical and economic variables. A distinction can be made between variables on farm setup, such as availability of land (on average, 52 ha for conventional and 56 ha for organic farms), milk quota (on average, $624,000 \mathrm{~kg}$ for conventional and $394,000 \mathrm{~kg}$ for organic farms), and other assets and variables indicating how well the farm is managed, ranging from milk production per cow and feeding costs per cow to gross margin per cow and family farm income.

\section{Selection of Risk Variables}

This research focused on the assessment of production and price risk in dairy farming. Production risk mainly stems from weather uncertainty affecting roughage production (quantity and quality) and from the inherent uncertainty in livestock production (e.g., diseases). Together with price risk (inputs and outputs), these factors jointly cause income risk. The analyzed risk variables in this paper are depicted in Figure 1. This analysis scheme captured the impact of technical and economic components on gross margin per dairy cow. Gross margin was chosen because it included all variable production and price factors. The use of gross margin per dairy cow excluded both fixed costs and income generated from other on-farm activities. Fixed costs were excluded because these have, by definition, a low variance, so there is low risk effect. Other on-farm activities were excluded because of lacking causal relations with dairy farming.

The relationships between the variables in the analysis scheme were mostly arithmetic, which meant that a variable could be calculated straightforward from its underlying variables. A few relationships in the scheme were causal but non arithmetic. An example is the relation between on-farm roughage production on the one hand and concentrate use and the expenditure on purchased roughage on the other hand. It is obvious that an increase of on-farm roughage production will affect concentrate use and expenditure on purchased roughage, but the effect cannot easily be calculated.

The gray boxes in Figure 1 represent the variables that were most important with regard to price and production risk. Price risk was captured by the variance in milk price and concentrate price. Production risk was included in the variance in milk production and content per cow, in veterinary costs, and in roughage production per hectare. Milk production per cow and veterinary costs per cow were directly measured.

On-farm roughage production per hectare was based on the assumption that supply and requirement of feed energy at herd level were equal. The assumption that the energy requirements of each animal, given its production and maintenance requirements, should exactly be met by the energy supplied to the animal is the basis of the Dutch VEM system for dairy cattle energy requirements (Van Es, 1978). Relevant input data regarding requirements stemmed from the Central Bureau for Livestock Feeding (CVB, 2007). The energy unit used was megajoules of $\mathrm{NE}_{\mathrm{L}}$ and calculations were done at herd level and on a yearly basis (Berentsen and Tiessink, 2003).

Total energy requirements followed from milk production and maintenance (including gestation) requirements of dairy cows and from growth and maintenance requirements of young stock. The following assumptions were used (CVB, 2007):

- Energy requirement for milk production is 3.17 MJ of $\mathrm{NE}_{\mathrm{L}} / \mathrm{kg}$ of fat- and protein-corrected milk (FPCM);

- Daily energy requirement for maintenance of dairy cows is 36.6 MJ of $\mathrm{NE}_{\mathrm{L}}$. Grazing during the daytime in summer, which is standard practice in the Netherlands, increases maintenance requirements, on average, by $5 \%$. Additional daily requirements for gestation are 3.11, 6.56, 10.4, and 18.6 MJ of $\mathrm{NE}_{\mathrm{L}}$ for mo 6, 7, 8, and 9 of gestation, respectively. Assuming a 1-yr calving interval, the total energy requirement per cow per year for maintenance including gestation is $365 \times 36.3 \times 1.05+30.5 \times$ $(3.11+6.56+10.4+18.6)=15.092 \mathrm{MJ}$ of $\mathrm{NE}_{\mathrm{L}}$;

- Daily energy requirement for young stock varies from 17.2 $\mathrm{MJ}$ of $\mathrm{NE}_{\mathrm{L}}$ in the first months to 51.8 $\mathrm{MJ}$ of $\mathrm{NE}_{\mathrm{L}}$ in the last months before calving. The total growing period spans, on average, 24 mo. Based on the increasing requirements per day as given by CVB (2007), the total requirement for the growing period of 24 mo amounts to 25,433 


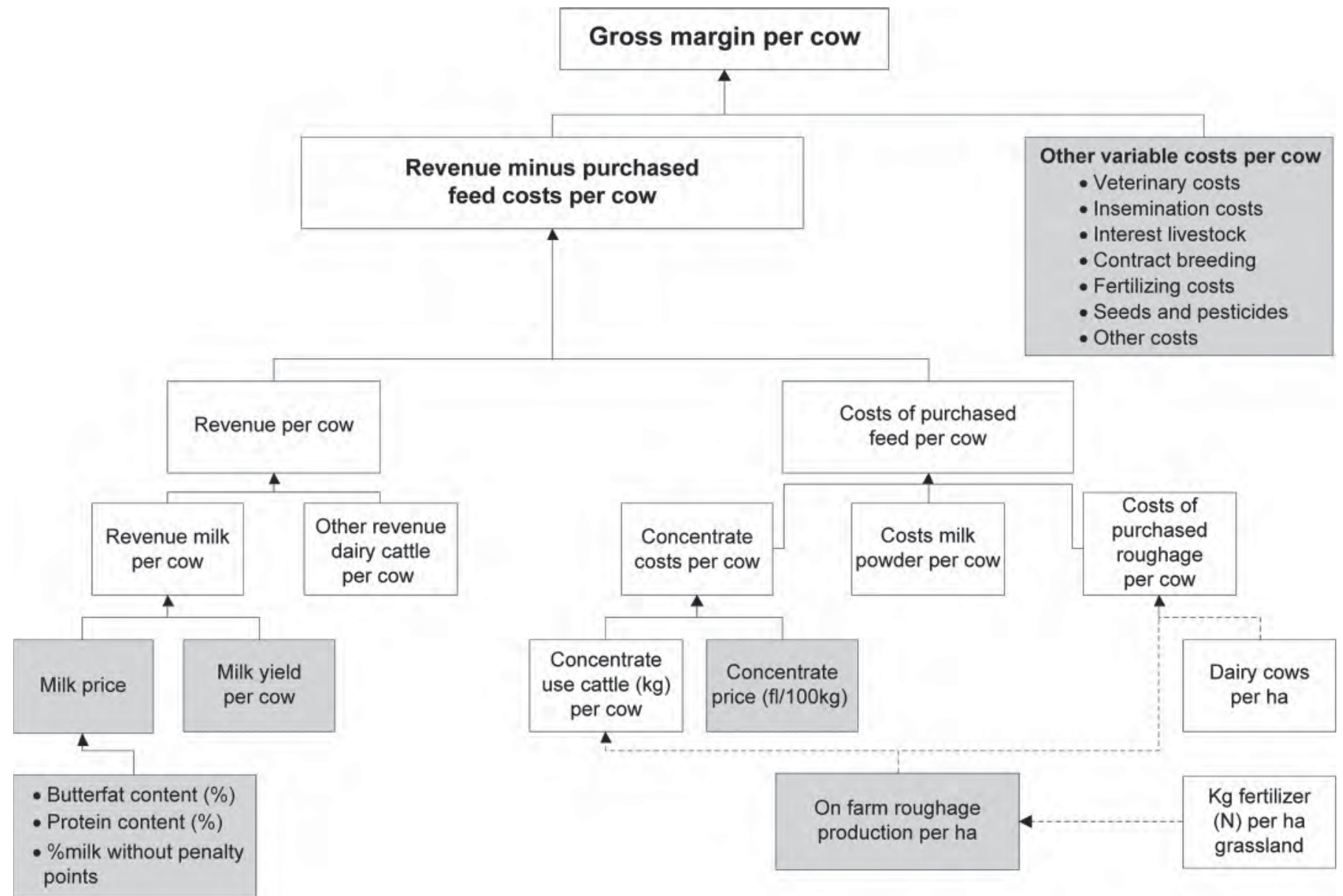

Figure 1. Scheme for analyzing gross margin per cow. Solid arrows indicate arithmetic relations. Dashed arrows indicate causal, but nonarithmetic relations. Shaded boxes show the risk variables used in this research.

MJ of $\mathrm{NE}_{\mathrm{L}}$. Per year, this totals $12,717 \mathrm{MJ}$ of $\mathrm{NE}_{\mathrm{L}}$. Assuming 0.7 young animals per dairy cow, this results in a feed requirement for young stock per dairy cow per year of $0.7 \times 12,717=8,902$ $\mathrm{MJ}$ of $\mathrm{NE}_{\mathrm{L}}$.

Note that these are all net energy requirements. Losses are incurred during grazing, roughage harvesting, and roughage and concentrate feeding. Here, it was assumed that, on average, $10 \%$ of the energy was lost during these processes. This resulted in the following total feed requirement per year for the farm:

$$
\begin{gathered}
\text { total energy requirement }=[\mathrm{FPCM} \times 3.17 \\
+ \text { no. of cows } \times(15.092+8,902)] / 0.9 .
\end{gathered}
$$

The total energy supplied consists of energy from purchased feed and energy from on-farm produced roughage. Purchased feed always involves concentrates but some farms also purchased roughage. However, the farm data did not include information on different types of purchased feed. The only information available was the total cost of purchased feed. To arrive at the total amount of purchased feed, costs of purchased feed were divided by the concentrate price times 6.48 (Eq. [2]):

$$
\begin{gathered}
\text { total purchased feed }=(\text { costs of purchased feed } / \\
\text { concentrate price per kilogram }) \times 6.48 .
\end{gathered}
$$

The latter value is the amount of $\mathrm{MJ}$ of $\mathrm{NE}_{\mathrm{L}}$ per kilogram of concentrate. Using the concentrate price as the price of all purchased feed is reasonable given the fact that a) in the Netherlands, the average amount of purchased roughage is low compared with the amount of concentrates and b) the price per $\mathrm{MJ}$ of $\mathrm{NE}_{\mathrm{L}}$ generally does not differ very much between different types of purchased feeds.

Knowing the total feed requirements from Eq. [1] and total purchased feed from Eq. [2], roughage production per hectare can be calculated according to Eq. [3]: 
roughage production per hectare $=$

total feed requirements - total purchased feed total area of grassland and feed crops

\section{Method of Analysis}

Differences in risk between conventional and organic farming result from differences in the within-farm standard deviations of the variables described in the previous section. For proper comparison, a farm-specific approach is essential, meaning that farm individual data need to be detrended for general observed trends such as weather variability (Flaten et al., 2011). A reason for doing so is that the individual farm data are not all from the same years. An example may explain this. Suppose that the standard deviations of roughage production of 2 farms are compared to determine their risk exposures. Next, suppose that the available data of the first farm span from 2001 to 2005, whereas those of the second farm span from 2004 to 2007 . Now, suppose that 2006 was a very dry year with extremely low roughage production all over the country. This would amplify the standard deviation of roughage production of the second farm, although this phenomenon is not specific for that particular farm. This could erroneously lead to the conclusion that, in general, the standard deviation of roughage production of the second farm is higher than on the first farm.

Following Atwood et al. (2003) and Flaten et al. (2011), detrending was done by means of an error component implicit detrending procedure. This included 4 successive steps (illustrated for FPCM) to derive timevariant farm-specific deviations:

1) compute the overall national average FPCM yield (nat) per cow $(Y)$ in each year $(t)\left(Y_{\text {nat }, t}\right)$;

2 ) compute the yield deviation $\left(\Delta_{i, t}\right)$ of each farm $i$ from the national yield for each year $t$ that the farm is in the sample:

$$
\Delta_{i, t}=Y_{i, t}-Y_{\text {nat }, t}
$$

where $Y_{i, t}$ is the average yield per cow of farm $i$ in year $t$;

3) compute the average (av) yield deviation over the years for each individual farm:

$$
\Delta_{i, \mathrm{av}}=Y_{i, \mathrm{av}}-Y_{n a t, \mathrm{av}, i}
$$

Note that the national average is specific for farm $i$, as it only refers to the years that farm $i$ is in the sample;
4) compute the time-variant farm-specific deviation $\left(\varepsilon_{i, t}\right)$ :

$$
\varepsilon_{i, t}=Y_{i, t}-Y_{n a t, t}-\left(Y_{i, a v}-Y_{n a t, a v, i}\right)
$$

After computing the time-variant farm-specific deviation for each of the $n$ years the farm is in the database, the SD per farm can be calculated as

$$
\mathrm{SD}=\sqrt{\frac{\sum_{t=1}^{n} \varepsilon_{i, t}^{2}}{t-1}}
$$

Finally, the average standard deviation for conventional farms (and similarly for organic farms) can be calculated as

$$
\begin{aligned}
& \mathrm{SD}_{\text {conventional }}= \\
& \frac{\sum \mathrm{SD}_{\text {conventional }}}{\text { number of conventional farms in the sample }}
\end{aligned}
$$

Besides means and standard deviations, coefficients of variation are derived to quantify the risk exposure to test possible differences in risk between conventional and organic farms. The coefficient of variation of a variable is the variable's standard deviation divided by its mean value.

\section{RESULTS}

Table 1 shows mean values and average detrended within-farm standard deviations of conventional and organic farms for different variables. The variables are grouped in 3 categories: economic result variables, price risk variables, and production risk variables.

The within-farm standard deviations of family farm income did not differ significantly between conventional and organic farms. The scale of milk production, however, was larger on conventional farms (on average, $624,000 \mathrm{~kg}$ for conventional and $394,000 \mathrm{~kg}$ for organic farms). This was confirmed by the mean family farm income in Table 1, which was much higher for conventional farming. Because of this difference in size, it made sense to do the comparison on a production factor basis.

The within-farm standard deviation of the gross margin per cow was significantly higher for organic farms. Several of the gross margin components for organic farms had a significantly higher within-farm standard deviation, specifically milk price, concentrate price, and milk yield. 
Table 1. Mean values and average detrended within-farm standard deviations of economic results and risk variables for organic and conventional farms and significance of differences ${ }^{1}$

\begin{tabular}{|c|c|c|c|c|c|c|}
\hline \multirow[b]{2}{*}{ Item } & \multicolumn{3}{|c|}{ Mean value } & \multicolumn{3}{|c|}{ Average detrended within-farm SD } \\
\hline & Conventional & Organic & $P$-value & Conventional & Organic & $P$-value \\
\hline Family farm income $(€)$ & 62,492 & 47,407 & 0.01 & 21,177 & 21,027 & 0.96 \\
\hline Gross margin per cow $(€)$ & 1,945 & 2,145 & 0.00 & 199 & 252 & 0.03 \\
\hline \multicolumn{7}{|l|}{ Price risk variable } \\
\hline Milk price $(€ / 10,000 \mathrm{~kg})$ & 3,432 & 3,906 & 0.00 & 82 & 190 & 0.00 \\
\hline Protein (\%) & 3.40 & 3.26 & 0.04 & 0.06 & 0.10 & 0.11 \\
\hline Milk with penalty points $(\mathrm{kg} /$ farm $)$ & 9,588 & 13,329 & 0.32 & 13,617 & 15,245 & 0.67 \\
\hline Concentrate price $(€ / 10,000 \mathrm{~kg})$ & 1,809 & 2,418 & 0.00 & 149 & 319 & 0.00 \\
\hline \multicolumn{7}{|l|}{ Production risk variable } \\
\hline Milk yield $(\mathrm{kg} \text { of } \mathrm{FPCM} / \mathrm{cow})^{2}$ & 7,924 & 6,417 & 0.00 & 361 & 470 & 0.02 \\
\hline Roughage production (MJ of $\mathrm{NE}_{\mathrm{L}} / \mathrm{ha}$ ) & 63,066 & 47,803 & 0.00 & 7,542 & 6,251 & 0.05 \\
\hline Veterinary cost $(€ /$ cow $)$ & 86.57 & 60.31 & 0.00 & 17.08 & 12.46 & 0.00 \\
\hline
\end{tabular}

${ }^{1}$ Data source: LEI (2012); own calculations.

${ }^{2} \mathrm{FPCM}=$ fat- and protein-corrected milk.

The standard deviation in milk price for organic farms was more than double of that from conventional farms. Volatility of the milk price could be caused by within-farm factors and by a volatile market. Withinfarm factors that might have caused part of the variation in milk price are milk quality factors, such as the fat and protein content of the milk and the percentage of milk without penalty points. Farms get penalty points for their milk (resulting in a lower milk price) if parameters such as the SCC or the total bacterial count are above an acceptable level [see Velthuis and van Asseldonk (2011) for a full explanation of the penalty system]. The standard deviations of all milk quality factors were higher for organic farming, but the differences in the standard deviations of these factors between conventional and organic farms were not significant. This indicates that the price received in the market fluctuated more for organic milk than for conventional milk, showing a higher output price risk for organic farming. Also, the difference in standard deviation between conventional and organic farms of concentrate prices was large and highly significant. As farmers generally cannot influence concentrate prices, the higher standard deviation of the organic concentrate price revealed a more extreme input price risk exposure for organic farming.

Regarding production risk, the standard deviation of milk yield per cow was significantly higher for organic farms. This difference was even more explicit if it was related to the level of milk yield, which was significantly lower for organic farms. From this, it is clear that milk yield per cow is more difficult to control in organic farming than in conventional farming. A higher standard deviation was estimated for roughage production per hectare in conventional farming, although the difference was not significant at the $P<0.05$ level. Related to the absolute level of roughage production per hectare, which was significantly higher for conventional farming, the difference in standard deviation was even less meaningful. The standard deviation of veterinary costs was significantly lower for organic farms. This, together with the lower absolute level of veterinary costs for organic farms, confirmed the more stable health situation on organic farms, which was also reported by Hardeng and Edge (2001).

Overall, the comparison of standard deviations in Table 1 shows that 3 factors contributed significantly to higher risk in organic farming. These are the milk and concentrate prices and the milk yield per cow.

Figure 2 shows the coefficients of variation for the different variables. Although the coefficients of variation for organic farms were significantly higher only for 3 variables, the overall picture is that, in general, the relative risk is higher in organic farming.

\section{DISCUSSION}

\section{Data and Methodological Considerations}

The FADN does not record any specific information with respect to roughage production, which was, therefore, indirectly calculated. Farms for which the assumptions used do not hold, end up with a biased mean roughage production. Wrong assumptions do not bias standard deviations so much, but via the mean they do bias the coefficient of variation. How- 


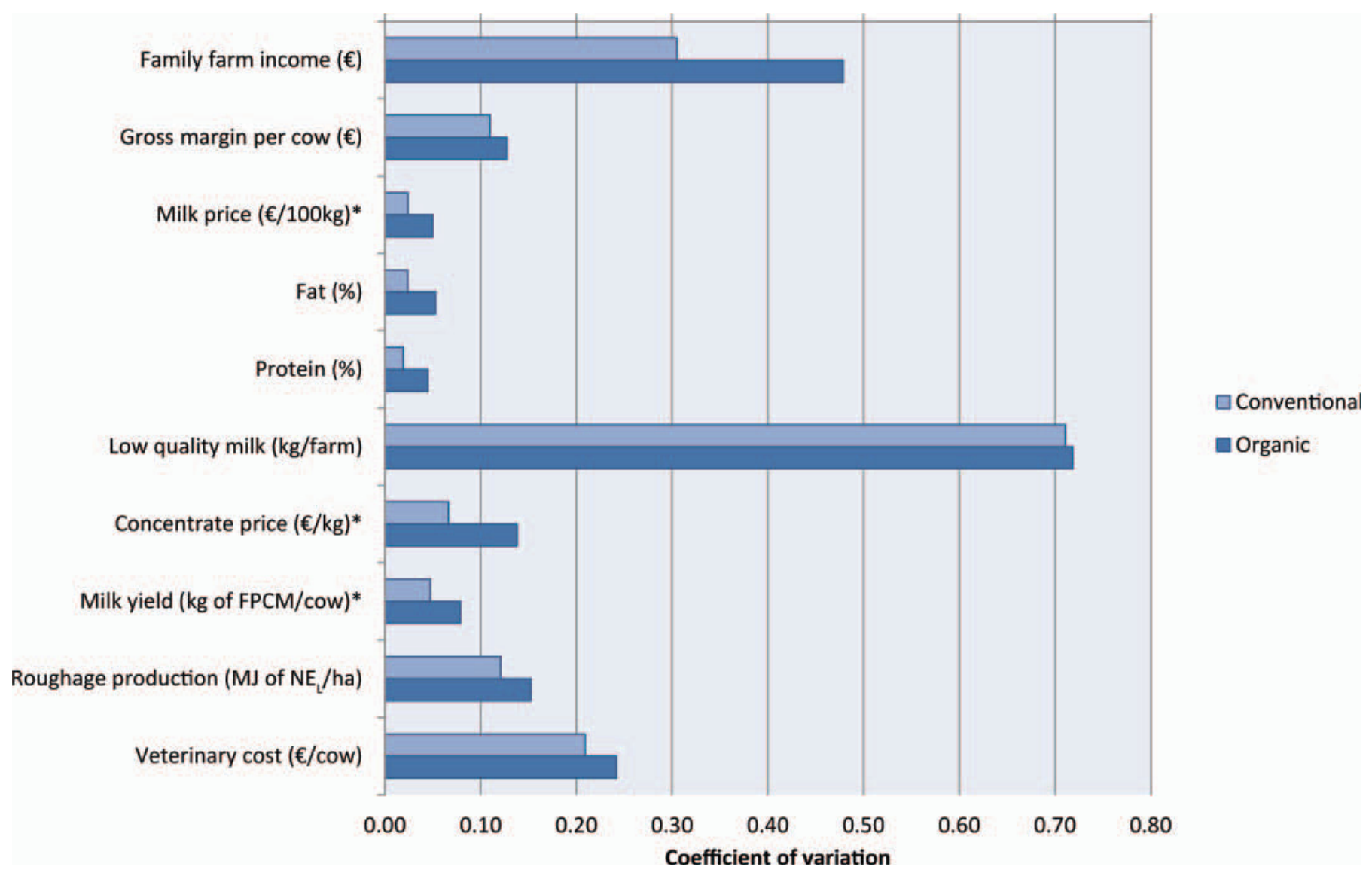

Figure 2. Average coefficients of variation for family farm income and its main components $(*=\mathrm{CV}$ different at the $P<0.05$ level). FPCM $=$ fat- and protein-corrected milk. Color version available in the online PDF.

ever, there is no indication why this error would not occur randomly and, thus, it is not expected that it would affect the estimated differences between the 2 groups of farms. Moreover, gross margin, which was the main variable in the analysis, did not depend on this procedure.

Detrending farm-level data was done using average data of all farms in the database. As the database is representative for dairy farming in the Netherlands, this means detrending at the national level. If substantial differences exist between regions, and if organic farms are concentrated in some regions, national detrending could lead to less reliable results (Flaten et al., 2011). However, given the fact that the Netherlands is a small country with little difference between regions, it is not very likely that a regional detrending procedure would generate more robust estimates than the current national approach applied. Moreover, conventional and organic milk production are quite similar in the sense that they experience similar effects from exogenous influencing factors such as weather. The detrending method can be easily adapted to compare not just within countries but also between different regions within a country.

\section{Risk Measurement}

This research presents several descriptive risk statistics for organic and conventional farms, namely averages, time-variant farm-specific standard deviations and coefficients of variation. Interpretation of differences in averages and standard deviations has its limitations for measuring risk. A more proper way to measure risk is to compute the coefficient of variation value, which is a relative value. Analyzing differences in coefficient of variation values confirms that price risk and milk production risk are significantly higher in organic farming. Note also that this indicator only captures part of the risk, and does not quantify, for example, downside risks (for example, the probability of negative farm income). A utility-based approach would capture the risk more appropriately, but would require additional subjective assumptions (Hardaker et al., 2004). 


\section{Attitude Toward Risk}

The results of this study show that organic dairy farming is more risky than conventional dairy farming. From this, it could be concluded that farmers that do convert to organic dairy farming might be less risk averse than their colleagues who do not convert under the same circumstances. A lower risk aversion of organic farmers is confirmed by other studies. A study by Flaten et al. (2005) comparing risk perception and risk management in conventional and organic dairy farming in Norway revealed that organic farmers perceive themselves as less risk averse than conventional farmers, which is an indication for being less risk averse. In an empirical study on arable farmers in the Netherlands, Gardebroek (2006) found that, on average, organic farmers have significantly lower coefficients of risk aversion than conventional farmers. Finally, the stochastic risk programming study on arable farming in the Netherlands of Acs et al. (2009) showed that only farmers with a low risk aversion coefficient would convert to organic farming.

\section{Risk Management}

In a study on risk perception and risk management in conventional and organic dairy farming in Norway (Flaten et al., 2005), it was found that risk management of conventional and organic farmers appeared to be remarkably similar. However, the impact of a similar strategy might be different because of the difference in the number of years between conventional and organic farms applying this strategy. Almost all conventional dairy farms have been operating conventionally as long as they exist (mostly several generations), whereas the majority of organic farms have converted to organic farming more recently. Because of being in the early phase of organic farming, these farms might have more volatile technical and economic results than conventional farms. It takes time to learn about differences in risk and to adapt management practices accordingly. In the long term, organic farmers might very well be able to enhance their risk management practices, bringing the risk level closer to that of conventional dairy farming.

\section{CONCLUSIONS}

The research objective was to assess and compare risks for conventional and organic farming in the Netherlands both regarding income and underlying price and production variables. The main variables concerning the comparison were family farm income from the core dairy business and gross margin per cow. We further- more analyzed the underlying components. The final results of this research are the selected variable's averages, detrended within-farm standard deviations, and the coefficients of variation of organic and conventional farms. The study used the error component implicit detrending method to arrive at robust results. The average family farm income was significantly higher on conventional farms than on organic farms, but the standard deviation was almost the same. Restricting income to gross margin and rescaling it to cow level, because of farm size differences, showed a significantly higher income risk for organic farming. Factors causing this higher risk were higher price risk for milk and concentrate and higher production risk regarding milk yield per cow. The higher price risk for milk is a pure market price risk and not a risk caused by variation in milk quality. Roughage production per hectare appeared not to involve a difference in production risk.

\section{ACKNOWLEDGMENTS}

The authors are grateful to the 2 anonymous reviewers for their helpful comments.

\section{REFERENCES}

Acs, S., P. B. M. Berentsen, and R. B. M. Huirne. 2007. Conversion to organic arable farming in the Netherlands: A dynamic linear programming analysis. Agric. Syst. 94:405-415.

Acs, S., P. B. M. Berentsen, R. B. M. Huirne, and M. A. P. M. van Asseldonk. 2009. Effect of yield and price risk on conversion from conventional to organic farming. Aust. J. Agric. Resour. Econ. 53:393-411.

Atwood, J., S. Shaik, and M. Watts. 2003. Are crop yields normally distributed? A reexamination. Am. J. Agric. Econ. 85:888-901.

Berentsen, P. B. M., and M. Tiessink. 2003. Potential effects of accumulating environmental policies on Dutch dairy farms. J. Dairy Sci. 86:1019-1028.

Butler, L. J. 2002. The economics of organic milk production in California: A comparison with conventional costs. Am. J. Altern. Agric. 17:83-91

Court of Auditors. 2004. Special Report No 14/2003 of the Court of Auditors concerning agricultural statistics measurement of farm incomes. Off. J. Eur. Union C45:1-26.

CVB (Central Bureau for Livestock Feeding). 2007. Tabellenboek veevoeding 2007 , voedernormen landbouwhuisdieren en voederwaarde veevoeders. Central Bureau for Livestock Feeding, The Hague, the Netherlands.

European Council. 1991. Regulation EEC No. 2092/1991. Regulation on organic production of agricultural products and indications referring thereto on agricultural products and foodstuffs. Off. J. Eur. Communities. L198:1-15.

European Council. 1999. Regulation EC No 1804/1999. Supplementing Regulation (EEC) No 2092/91 on organic production of agricultural products and indications referring thereto on agricultural products and foodstuffs to include livestock production. Off. J. Eur. Communities. L222:1-28.

Flaten, O., and G. Lien. 2007. Stochastic utility-efficient programming of organic dairy farms. Eur. J. Oper. Res. 181:1574-1583.

Flaten, O., G. Lien, M. Koesling, P. S. Valle, and M. Ebbesvik. 2005. Comparing risk perceptions and risk management in organic and 
conventional dairy farming: Empirical results from Norway. Livest. Prod. Sci. 95:11-25.

Flaten, O., G. Lien, and R. Tveterås. 2011. A comparative study of risk exposure in agriculture and aquaculture. Acta Agric. Scand. C Food Econ. 8:20-34.

Gardebroek, C. 2006. Comparing risk attitudes of organic and nonorganic farmers with a Bayesian random coefficient model. Eur. Rev. Agric. Econ. 33:485-510.

Hardaker, J. B., R. B. M. Huirne, J. R. Anderson, and G. Lien. 2004. Coping with Risk in Agriculture. Centre for Agricultural Bioscience International (CABI), Wallingford, UK.

Hardeng, F., and V. L. Edge. 2001. Mastitis, ketosis, and milk fever in 31 organic and 93 conventional Norwegian dairy herds. J. Dairy Sci. 84:2673-2679.

Huirne, R. B. M., M. P. M. Meuwissen, and M. A. P. M. van Asseldonk. 2007. Importance of whole-farm risk management in agriculture. Pages 3-15 in Handbook of Operations Research in Natural Resources, Volume 99. A. Weintraub, C. Romero, T. Bjørndal, R. Epstein, and J. Miranda, ed. Springer Science+Business Media LLC, New York, NY.

Lampkin, N. H. 1994. Organic farming: Sustainable agriculture in practice. Pages 3-9 in The Economics of Organic Farming: An International Perspective. N. H. Lampkin and S. Padel, ed. Centre for Agricultural Bioscience International (CABI), Wallingford, UK.

LEI (Agricultural Economics Research Institute). 2012. Farm Information Network. Accessed Jan. 20, 2012. http://www3.lei.wur.nl/ BIN_ASP/show.exe.

Ogurtsov, V. A., M. A. P. M. van Asseldonk, and R. B. M. Huirne. 2008. Assessing and modelling catastrophic risk perceptions and attitudes in agriculture: A review. Wageningen J. Life Sci. 56:3958.

Ogurtsov, V. A., M. A. P. M. van Asseldonk, and R. B. M. Huirne. 2009. Purchase of catastrophe insurance by Dutch dairy and arable farmers. Appl. Econ. Perspect. Pol. 3:143-162.
Padel, S. 2001. Conversion to organic farming: A typical example of the diffusion of an innovation? Sociol. Ruralis 41:40-61.

Padel, S., N. H. Lampkin, S. Dabbert, and C. Foster. 2002. Organic farming policy in the European Union. Pages 169-194 in Advances in the Economics of Environmental Resources. Vol. 4. D. C. Hall and L. J. Moffitt, ed. Emerald Group Publishing Ltd., Bingham, UK.

Ray, K. A., L. D. Warnick, R. M. Mitchell, J. B. Kaneene, P. L. Ruegg, S. J. Wells, C. P. Fossler, L. W. Halbert, and K. May. 2006. Antimicrobial susceptibility of Salmonella from organic and conventional dairy farms. J. Dairy Sci. 89:2038-2050.

Rigby, D., and C. Cáceres. 2001. Organic farming and the sustainability of agricultural systems. Agric. Syst. 68:21-40.

Roesch, M., M. G. Doherr, and J. W. Blum. 2005. Performance of dairy cows on Swiss farms with organic and integrated production. J. Dairy Sci. 88:2462-2475.

Rotz, C. A., G. H. Kamphuis, H. D. Karsten, and R. D. Weaver. 2007. Organic dairy production systems in Pennsylvania: A case study evaluation. J. Dairy Sci. 90:3961-3979.

Stichting Skal. 2012. Biol. Controll (in Dutch). Accessed Jan. 6, 2012 http://www.skal.nl/Home/tabid/36/Default.aspx.

Stonehouse, D. P.. E. A. Clark, and Y. A. Ogini. 2001. Organic and conventional dairy farm comparisons in Ontario Canada. Biol. Agric. Hortic. 19:115-125.

Van Es, A. J. H. 1978. Feed evaluation for ruminants. I. The systems in use in use from May 1977-onwards in the Netherlands. Livest. Prod. Sci. 5:331-345.

Velthuis, A. G. J., and M. A. P. M. van Asseldonk. 2011. Process audits versus product quality monitoring of bulk milk. J. Dairy Sci. 94:235-249. 